\title{
The pentapeptide RM-131 promotes food intake and adiposity in wildtype mice but not in mice lacking the ghrelin receptor
}

\section{Katrin Fischer ${ }^{1,2}$, Brian Finan ${ }^{1,2}$, Christoffer Clemmensen ${ }^{1,2}$, Lex H. T. van der Ploeg ${ }^{3}$, Matthias H. Tschöp ${ }^{1,2}$ and Timo D. Müller ${ }^{1,2 *}$}

\author{
1 Institute for Diabetes and Obesity (IDO) and Helmholtz Diabetes Center, Helmholtz Center Munich, German Research Center for Environmental Health (GmbH), \\ Neuherberg, Germany \\ 2 Division of Metabolic Diseases, Department of Medicine, Technische Universität München, Munich, Germany \\ ${ }^{3}$ Rhythm Pharmaceuticals Inc., Boston, MA, USA
}

\section{Edited by:}

Susie Swithers, Purdue University, USA

\section{Reviewed by:}

Ulrich Schweiger, Lübeck University

Medical School, Germany

Scott E. Kanoski, University of

Southern California, USA

\section{*Correspondence:}

Timo D. Müller, Institute for Diabetes and Obesity (IDO), Business Campus Garching-Hochbrück, Parkring 13,

Garching 85748, Germany

e-mail: timo.mueller@

helmholtz-muenchen.de
The gastrointestinal peptide hormone ghrelin is the endogenous ligand of the growth hormone secretagogue receptor (a.k.a. ghrelin receptor, GHR). Currently, ghrelin is the only circulating peripheral hormone with the ability to promote a positive energy balance by stimulating food intake while decreasing energy expenditure and body fat utilization, as defined in rodents. Based on these and additional, beneficial effects on metabolism, the endogenous ghrelin system is considered an attractive target to treat diverse pathological conditions including those associated with eating/wasting disorders and cachexia. As the pharmacological potential of ghrelin is hampered by its relatively short half-life, ghrelin analogs with enhanced pharmacokinetics offer the potential to sustainably improve metabolism. One of these ghrelin analogs is the pentapeptide RM-131, which promotes food intake and adiposity with higher potency as compared to native ghrelin in rodents. Whereas, the effect of RM-131 on energy metabolism is solidly confirmed in rodents, it remains elusive whether RM-131 exerts its effect solely via the ghrelin receptor. Accordingly, we assessed the receptor specificity of RM-131 to promote food intake and adiposity in mice lacking the GHR. Our data show that in wildtype mice RM-131 potently promotes weight gain and adiposity through stimulation of food intake. However, RM-131 fails to affect food intake and body weight in mice lacking the GHR, underlining that the anabolic effects of RM-131 are mediated via the ghrelin receptor in mice.

Keywords: ghrelin, RM-131, food intake, adiposity, GHSR1a, GHR

\section{INTRODUCTION}

The gastrointestinal peptide hormone ghrelin is a key peripheral hormone implicated in a myriad of metabolic functions. Presently, ghrelin is the only known peripheral hormone that promotes body weight gain and adiposity through stimulation of food intake while decreasing energy expenditure and lipid utilization (1). In addition to its ability to regulate energy metabolism via hypothalamic $(2-4)$ and non-hypothalamic $(5,6)$ neurocircuits, ghrelin exerts a series of effects on metabolism. Accordingly, ghrelin acutely promotes the release of growth hormone from the anterior pituitary (7) regulates glucose metabolism upon chronic systemic treatment $(8,9)$, stimulates lipogenesis in white adipose tissue (10), acutely enhances gastric acid secretion and gut motility (11-13), modulates reward seeking behavior and taste sensation (14-17), lowers non-shivering thermogenesis of brown adipose tissue $(18,19)$, has cardioprotective effects $(20$ $22)$, and protects against muscle atrophy $(23,24)$. In line with a growing number of preclinical and clinical studies, the numerous beneficial effects of ghrelin make the endogenous ghrelin system an attractive therapeutic target for a series of pathological conditions. As such, ghrelin and its analogs might offer potential to treat cachexia $(25,26)$, sarcopenia $(27)$, myopenia (28), gastroparesis (29), or anorexia nervosa (26) whereas inhibition of ghrelin signaling might offer potential to treat obesity and diabetes (30).

Ghrelin promotes its biologic action via activation of the growth hormone secretagogue receptor (GHSR, also referred to as the ghrelin receptor; GHR), a seven transmembrane G proteincoupled receptor with wide distribution in human tissues (31, 32). A spliced variant of the GHR, the GHSRla seems to be the only endogenous active ghrelin receptor, since neither central (33) nor peripheral (34) ghrelin administration affects systems metabolism in mice lacking the GHR gene. To bind and activate its receptor, ghrelin requires acylation of its serine 3 residue with an n-octanoic or n-decanoic acid (7), a post-translational modification achieved by the ghrelin-O-acyltransferase (GOAT) $(35,36)$. Whereas, the pharmacological potential of GHR pathway modulation has been emphasized in a series of preclinical and clinical studies [as reviewed in Ref. $(26,37)$ ], the efficacy of acyl-ghrelin to improve systems metabolism is hampered by its relatively short half-life, which, depending on the species, varies between $30 \mathrm{~min}$ in rats and 240 min in humans (38). 
Whereas, the pharmacological potential of acyl-ghrelin is limited by its rapid degradation and the fragility of its serine 3 acylation, ghrelin mimetics offer potential to more sustainably improve systems metabolism. The pentapeptide RM-131 (BIM28131) confers increased bioavailability and improved pharmacokinetic properties as compared to the native peptide. RM-131 has a high in vitro affinity to bind and activate GHSR1a (39) and its chronic systemic administration in rodents increases body weight gain and adiposity through stimulation of food intake (40-42). The orexigenic effects of RM-131 are mediated by stimulation of meal size, meal numbers, and meal duration $(41,43)$ and are paralleled by increased c-fos immunoreactivity in arcuate nucleus AgRP/NPY neurons (43). Similar to ghrelin, RM-131 stimulates growth hormone release from the anterior pituitary (43), increases GI motility and gastric emptying $(39,44,45)$, and reduces inflammation and tissue wasting in animal models of cachexia $(40,46,47)$ and of inflammatory bowel disease $(39,40)$. Compared to native human ghrelin, RM-131 is about 10 - to 100 -fold more potent, and it is 600 - to 1,800 -fold more potent compared to ghrelin mimetics tested thus far in clinical trials (39). The first clinical studies using RM-131, which is in phase 2 clinical trials for the treatment of diabetic gastroparesis and intestinal dysmotility disorders, report that a single subcutaneous administration of RM-131 accelerates gastric emptying in type 2 diabetic patients with gastroparesis (45). These and a series of preclinical data support the therapeutic potential of RM-131 to improve systems metabolism. However, uncertainty remains about whether RM-131 exerts its in vivo effects solely via GHSR1a signaling. In this study, we assessed whether the anabolic action of RM-131 is exclusively attributable to GHSR1a signaling in mice. In line with previous reports, we show that RM-131 potently enhances both acute and chronic food intake and adiposity in wildtype (wt) mice. We show that RM-131 has no effect on food intake, body weight, and adiposity in mice lacking the GHR. In summary, our data support the therapeutic potential of RM-131 to accelerate caloric intake and weight gain and indicate that the in vivo anabolic effects of RM-131 are exclusively mediated via the ghrelin receptor in mice.

\section{MATERIALS AND METHODS}

\section{ANIMALS AND ACUTE FOOD INTAKE ASSESSMENTS}

All animal experiments and procedures were approved by the Animal Use and Care Committee of Bavaria, Germany. The mice were on a pure $\mathrm{C} 57 \mathrm{BL} / 6 \mathrm{~J}$ background and were bred in house under standard laboratory conditions (constant humidity, 12/12 h light dark cycle, $22 \pm 1^{\circ} \mathrm{C}$ ). For the measurement of $24 \mathrm{~h}$ acute food intake, non-fasted mice were single housed whereas for the 7-day chronic study the mice were double-housed. All test compounds were solved in $\mathrm{H}_{2} \mathrm{O}$ containing 5\% mannitol. The effect of RM-131 on acute food intake was assessed in 10-week-old male chow-fed C57BL6/J wt $(N=40 ; 26.71 \pm 0.14 \mathrm{~g})$ and GHR knock-out (ko) mice $(N=40 ; 26.75 \pm 0.22 \mathrm{~g})$. Mice were matched for body weight and body fat mass ( $N=8$ each group) and treated with a single subcutaneous injection of either rat ghrelin $(500$ or $5,000 \mathrm{nmol} / \mathrm{kg}$, PolyPeptide Laboratories, Strasbourg, France), RM-131 (250 or $500 \mathrm{nmol} / \mathrm{kg})$ or vehicle control $\left(\mathrm{H}_{2} \mathrm{O}\right.$ containing $5 \%$ mannitol). Acute food intake was measured at time points $0.5,1,2,4,8,12$, and $24 \mathrm{~h}$ post-ghrelin treatment.

\section{CHRONIC PERIPHERAL TREATMENT OF RM-131 IN WT AND GHR KO MICE}

The chronic effect of RM-131 on body weight, body composition (fat and lean mass), and food intake was measured in 13-week old male chow-fed C57BL6/J wt $(N=32 ; 28.09 \pm 0.2 \mathrm{~g})$ and GHR ko mice $(N=32 ; 28.36 \pm 0.24 \mathrm{~g})$. The mice were matched for body weight and body fat mass $(N=8$ each group) and treated for seven consecutive days via daily subcutaneous injections of either rat ghrelin $(5,000 \mathrm{nmol} / \mathrm{kg}$ ), RM-131 (50 or $500 \mathrm{nmol} / \mathrm{kg}$ ), or vehicle $\left(\mathrm{H}_{2} \mathrm{O}\right.$ containing 5\% mannitol). Body composition (fat and lean tissue mass) was assessed at study day 7 using MRI technology (EchoMRI, Houston, TX, USA) as previously described (48).

\section{DATA ANALYSIS}

Differences between treatment groups were assessed by one-way or two-way ANOVA followed by Bonferroni post hoc test as appropriate. All results are given as means \pm SEM. Results were considered statistically significant when $p<0.05$, with the significance level indicated as ${ }^{\star}(p<0.05),{ }^{* *}(p<0.01)$, and ${ }^{* *}(p<0.001)$.

\section{RESULTS \\ RM-131 STIMULATES ACUTE FOOD INTAKE IN WT BUT NOT GHR KO MICE}

To assess the effects of RM-131 and ghrelin on acute food intake, C57Bl/6J wt and GHR ko mice were treated with a single subcutaneous injection of either rat ghrelin (500 and 5,000 nmol/ $\mathrm{kg}$ ), RM-131 (250 and $500 \mathrm{nmol} / \mathrm{kg}$ ), or vehicle control. In wt mice, we observed an immediate dose-dependent increase in acute food intake following administration of both ghrelin (Figures 1A,B) and RM-131 (Figures 1C,D). For both ghrelin and RM-131, the greatest peak of compound-stimulated food intake was observed $2 \mathrm{~h}$ post-injection (Figure 1E). In line with previous reports indicating that RM-131 has a greater potency to promote food intake relative to native ghrelin (42), we observed a greater increase in food intake in mice treated with $500 \mathrm{nmol} / \mathrm{kg}$ RM-131 (area under curve $p<0.001$, Figure $1 \mathrm{~K}$ ) as compared to an equimolar dose of native ghrelin (area under curve $p<0.01$, Figure 1K). Importantly, we observed neither for RM-131 nor for ghrelin an effect on acute food intake in the GHR ko mice (Figures 1F-K) with a similar $24 \mathrm{~h}$ time-course of food intake between the vehicle treated $\mathrm{wt}$ mice and all treatment groups of the GHR ko mice (all $p>0.05$ ).

\section{CHRONIC SYSTEMIC ADMINISTRATION OF RM-131 PROMOTES BODY WEIGHT GAIN AND ADIPOSITY THROUGH GHR SIGNALING}

To assess the chronic effects of RM-131 on food intake and adiposity, C57Bl/6J wt and GHR ko mice were treated for seven consecutive days with once daily subcutaneous injections of RM-131 (50 and $500 \mathrm{nmol} / \mathrm{kg})$, rat ghrelin $(5,000 \mathrm{nmol} / \mathrm{kg})$, or vehicle control. In wt mice, administration of rat ghrelin $(5,000 \mathrm{nmol} / \mathrm{kg})$ significantly increased body weight and body fat mass relative to vehicle treated controls (Figures 2A,B). Neither food intake nor lean tissue mass was different between the ghrelin treated wt mice and vehicle treated controls (Figures 2B,C). Treatment of wt mice with RM-131 at concentrations of 50 or $500 \mathrm{nmol} / \mathrm{kg}$ both increased body weight relative to vehicle controls (both $p<0.01$ ). However, body weight gain was significantly greater in mice treated with $500 \mathrm{nmol} / \mathrm{kg} \mathrm{RM-131} \mathrm{compared} \mathrm{to} \mathrm{mice} \mathrm{treated} \mathrm{with} 50 \mathrm{nmol} / \mathrm{kg}$ 

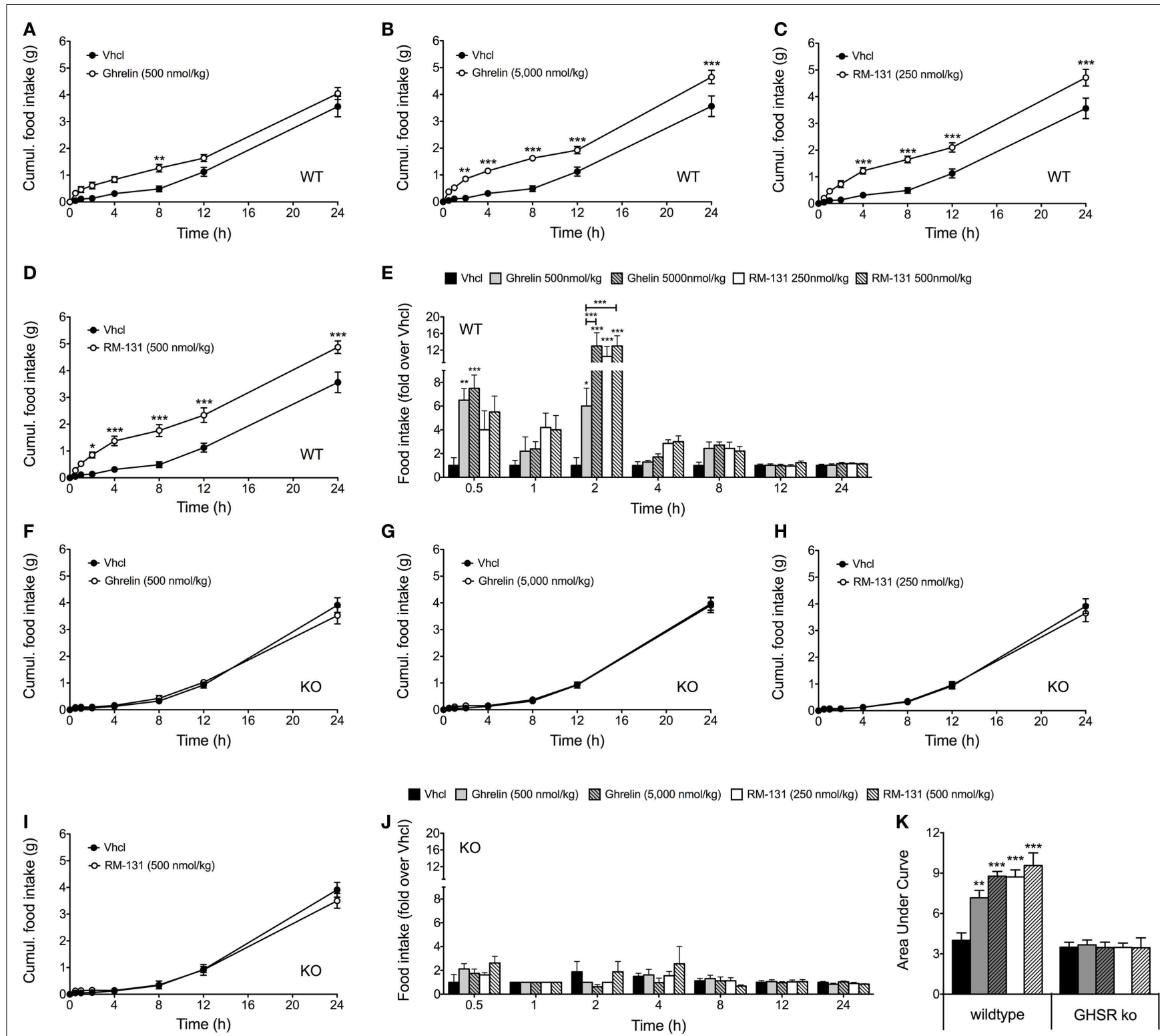

FIGURE 1 | Acute effect of RM-131 on food intake in wt and GHR ko mice. Acute $24 \mathrm{~h}$ food intake in C57BI/6J wt and GHR ko mice treated with a single subcutaneous injection of vehicle, ghrelin (500 or $5,000 \mathrm{nmol} / \mathrm{kg}$ ) or RM-131 (250 or $500 \mathrm{nmol} / \mathrm{kg}$ ) (A-K). Effects on $24 \mathrm{~h}$ cumulative food intake (A-D,F-I), fold-increase in food intake relative to mice treated with vehicle $\mathbf{( E ,}, \mathbf{J})$, and area under curve of the 24-h food intake (K). $N=8$ mice each genotype and treatment group. Data represent means \pm SEM. Asterisks indicate ${ }^{*} p<0.05$; ${ }^{* *} p<0.01 ;{ }^{* *} p<0.001$.
RM-131 $(p<0.0001)$ and as compared to mice treated with a 10fold higher dose of ghrelin $(5,000 \mathrm{nmol} / \mathrm{kg} ; p<0.05)$ (Figure 2A). As in the ghrelin treated mice, mice treated with RM-131 displayed an increase in body weight that was a result of an increase in body fat but not lean tissue mass (Figure 2B). Notably, food intake was increased only in wt mice treated with $500 \mathrm{nmol} / \mathrm{kg}$ RM-131 $(p<0.05)$ but not in mice treated with $50 \mathrm{nmol} / \mathrm{kg} \mathrm{RM-}$ 131 or $5,000 \mathrm{nmol} / \mathrm{kg}$ ghrelin (Figure $2 \mathrm{C}$ ). In line with our study showing that RM-131 promotes food intake exclusively via the GHR, we observed no effect of RM-131 at concentrations of 50 or $500 \mathrm{nmol} / \mathrm{kg}$ on body weight (Figure 2D), body composition
(Figure 2E), or food intake (Figure 2F) in the GHR ko mice relative to their vehicle treated controls.

\section{DISCUSSION}

A series of preclinical and clinical data support the therapeutic potential of ghrelin and its analogs to improve pathological conditions associated with eating/wasting disorders and cachexia (26), intestinal dysmotility disorders (49), and diabetic gastroparesis $(39,44,45)$. However, whereas the therapeutic potential of GHSR1a pathway modulation is generally acknowledged, the pharmacological value of native ghrelin is limited by its rapid 


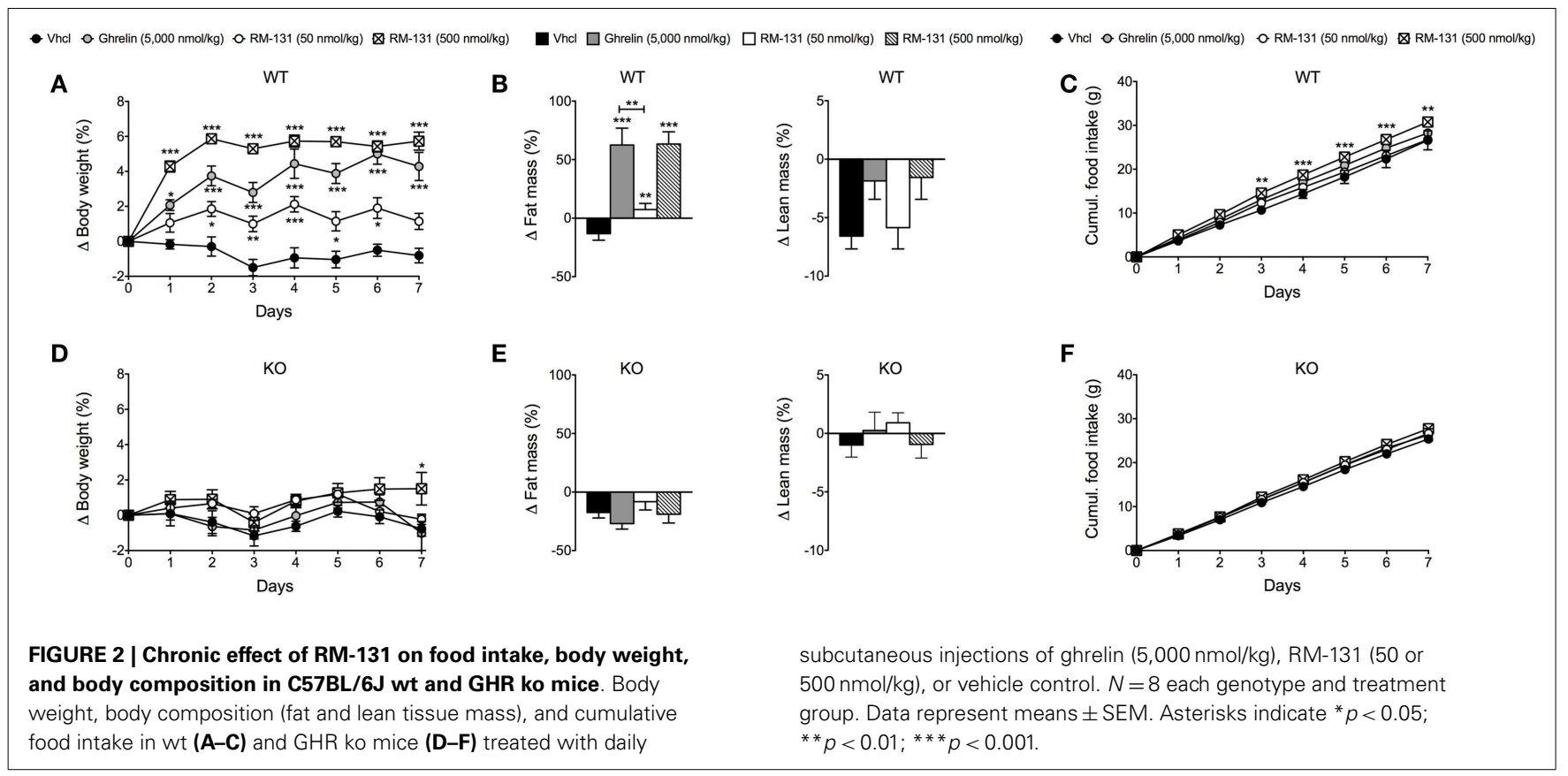

degradation and the fragility of its serine 3 acylation. Several clinical studies report beneficial effects of ghrelin administration on food intake in healthy individuals (50-52), patients with anorexia nervosa (53), and in patients with cachexia associated with cancer (54), chronic obstructive pulmonary disease (COPD) (55) and renal failure $(56,57)$. However, not all studies were able to replicate these findings $(25,58,59)$. Potential pitfalls of these studies are the limited amount of patients analyzed and the overall short duration of ghrelin treatment. Nevertheless, based on the relative short half-life of the native peptide, ghrelin mimetics, which overcome these issues are predicted to more sustainably improve metabolic and other clinical parameters. Several clinical studies have assessed the therapeutic potential of ghrelin mimetics, such as anamorelin (RC-1291) (52), ulimorelin (TZP-101) (60-62), and RM-131 $(44,45)$ for the treatment of cachexia, gastroparesis, and gastric/intestinal dysmobility disorders. Whereas, TZP-101 had only limited success to improve gastroparesis in a large-scale clinical study (63), the pentapeptide RM-131, exerts superior effects on systems metabolism as compared to native ghrelin and other ghrelin mimetics so far tested in clinical trials (39). However, it remains elusive whether RM-131 exerts its in vivo anabolic effects exclusively via GHR activation. Accordingly, the aim of this study was to assess whether RM-131 promotes food intake and adiposity via GHR signaling in vivo. In line with previous studies, our data show that in wt mice, RM-131 potently enhances food intake, body weight, and adiposity. We show that RM-131 has no effect on food intake and body weight gain in mice lacking the GHR (including the active/spliced variant GHSR1a), indicating that the anabolic effects of RM-131 are exclusively mediated via the ghrelin receptor in mice.

In summary, our data align with numerous reports indicating that GHSR1a pathway modulation is a promising and powerful tool to promote food intake and adiposity, underscoring the therapeutic potential of manipulating the endogenous ghrelin system to treat pathological conditions associated with excessive tissue wasting and cachexia. Our data also support previous findings indicating that RM-131 promotes its biological action at concentrations 10- to 100-fold lower than native ghrelin. However, whereas our studies clearly show that RM-131 promotes food intake and adiposity exclusively via the ghrelin receptor in mice, more studies are warranted to assess whether more complex functions of ghrelin, such as the regulation of reward seeking behavior, taste sensation, and protection of muscle atrophy, are mediated via RM-131-GHSR1a interaction. In addition, based on the superior anabolic efficacy of RM-131 compared to native ghrelin, RM-131 holds promise for proof of concept experiments in mice to evaluate potentially clinically beneficial effects of RM-131 in diet-induced obesity, with relative ghrelin resistance (64).

\section{AUTHOR CONTRIBUTIONS}

Katrin Fischer, Brian Finan, Christoffer Clemmensen, and Timo D. Müller conducted the experiments, participated in study design and interpretation of the data, and drafted the manuscript. Matthias H. Tschöp and Lex H. T. Van Der Ploeg participated in conceiving the experiments, revised the data critically, and helped editing the manuscript.

\section{ACKNOWLEDGMENTS}

This work was supported by grants from the German Research Foundation (DFG-TS226/1-1).

\section{REFERENCES}

1. Tschop M, Smiley DL, Heiman ML. Ghrelin induces adiposity in rodents. Nature (2000) 407:908-13. doi:10.1038/35038090

2. Cowley MA, Smith RG, Diano S, Tschop M, Pronchuk N, Grove KL, et al. The distribution and mechanism of action of ghrelin in the CNS demonstrates a novel hypothalamic circuit regulating energy homeostasis. Neuron (2003) 37:649-61. doi:10.1016/S0896-6273(03)00063-1

3. Chen HY, Trumbauer ME, Chen AS, Weingarth DT, Adams JR, Frazier EG, et al. Orexigenic action of peripheral ghrelin is mediated by neuropeptide $Y$ 
and agouti-related protein. Endocrinology (2004) 145:2607-12. doi:10.1210/en. 2003-1596

4. Luquet S, Phillips CT, Palmiter RD. NPY/AgRP neurons are not essential for feeding responses to glucoprivation. Peptides (2007) 28:214-25. doi:10.1016/j. peptides.2006.08.036

5. Faulconbridge LF, Cummings DE, Kaplan JM, Grill HJ. Hyperphagic effects of brainstem ghrelin administration. Diabetes (2003) 52:2260-5. doi:10.2337/ diabetes.52.9.2260

6. Faulconbridge LF, Grill HJ, Kaplan JM. Distinct forebrain and caudal brainstem contributions to the neuropeptide Y mediation of ghrelin hyperphagia. Diabetes (2005) 54:1985-93. doi:10.2337/diabetes.54.7.1985

7. Kojima M, Hosoda H, Date Y, Nakazato M, Matsuo H, Kangawa K. Ghrelin is a growth-hormone-releasing acylated peptide from stomach. Nature (1999) 402:656-60. doi:10.1038/45230

8. Date Y, Nakazato M, Hashiguchi S, Dezaki K, Mondal MS, Hosoda H, et al. Ghrelin is present in pancreatic alpha-cells of humans and rats and stimulates insulin secretion. Diabetes (2002) 51:124-9. doi:10.2337/diabetes.51.1.124

9. Reed JA, Benoit SC, Pfluger PT, Tschop MH, D’alessio DA, Seeley RJ. Mice with chronically increased circulating ghrelin develop age-related glucose intolerance. Am J Physiol Endocrinol Metab (2008) 294:E752-60. doi:10.1152/ajpendo. 00463.2007

10. Theander-Carrillo C, Wiedmer P, Cettour-Rose P, Nogueiras R, Perez-Tilve D, Pfluger P, et al. Ghrelin action in the brain controls adipocyte metabolism. JClin Invest (2006) 116:1983-93. doi:10.1172/JCI25811

11. Masuda Y, Tanaka T, Inomata N, Ohnuma N, Tanaka S, Itoh Z, et al. Ghrelin stimulates gastric acid secretion and motility in rats. Biochem Biophys Res Commun (2000) 276:905-8. doi:10.1006/bbrc.2000.3568

12. Asakawa A, Inui A, Kaga T, Yuzuriha H, Nagata T, Ueno N, et al. Ghrelin is an appetite-stimulatory signal from stomach with structural resemblance to motilin. Gastroenterology (2001) 120:337-45. doi:10.1053/gast.2001.22158

13. Avau B, Carbone F, Tack J, Depoortere I. Ghrelin signaling in the gut, its physiological properties, and therapeutic potential. Neurogastroenterol Motil (2013) 25:720-32. doi:10.1111/nmo.12193

14. Jerlhag E, Egecioglu E, Dickson SL, Andersson M, Svensson L, Engel JA. Ghrelin stimulates locomotor activity and accumbal dopamine-overflow via central cholinergic systems in mice: implications for its involvement in brain reward. Addict Biol (2006) 11:45-54. doi:10.1111/j.1369-1600.2006.00002.x

15. Jerlhag E, Egecioglu E, Dickson SL, Douhan A, Svensson L, Engel JA. Ghrelin administration into tegmental areas stimulates locomotor activity and increases extracellular concentration of dopamine in the nucleus accumbens. Addict Biol (2007) 12:6-16. doi:10.1111/j.1369-1600.2006.00041.x

16. Tong J, Mannea E, Aime P, Pfluger PT, Yi CX, Castaneda TR, et al. Ghrelin enhances olfactory sensitivity and exploratory sniffing in rodents and humans. J Neurosci (2011) 31:5841-6. doi:10.1523/JNEUROSCI.5680-10.2011

17. Skibicka KP, Hansson C, Egecioglu E, Dickson SL. Role of ghrelin in food reward: impact of ghrelin on sucrose self-administration and mesolimbic dopamine and acetylcholine receptor gene expression. Addict Biol (2012) 17:95-107. doi:10.1111/j.1369-1600.2010.00294.x

18. Yasuda T, Masaki T, Kakuma T, Yoshimatsu H. Centrally administered ghrelin suppresses sympathetic nerve activity in brown adipose tissue of rats. Neurosci Lett (2003) 349:75-8. doi:10.1016/S0304-3940(03)00789-4

19. Tsubone T, Masaki T, Katsuragi I, Tanaka K, Kakuma T, Yoshimatsu H. Ghrelin regulates adiposity in white adipose tissue and UCP1 mRNA expression in brown adipose tissue in mice. Regul Pept (2005) 130:97-103. doi:10.1016/j. regpep.2005.04.004

20. Nagaya N, Uematsu M, Kojima M, Ikeda Y, Yoshihara F, Shimizu W, et al. Chronic administration of ghrelin improves left ventricular dysfunction and attenuates development of cardiac cachexia in rats with heart failure. Circulation (2001) 104:1430-5. doi:10.1161/hc3601.095575

21. Okumura H, Nagaya N, Enomoto M, Nakagawa E, Oya H, Kangawa K. Vasodilatory effect of ghrelin, an endogenous peptide from the stomach. J Cardiovasc Pharmacol (2002) 39:779-83. doi:10.1097/00005344-200206000-00001

22. Nagaya N, Moriya J, Yasumura Y, Uematsu M, Ono F, Shimizu W, et al. Effects of ghrelin administration on left ventricular function, exercise capacity, and muscle wasting in patients with chronic heart failure. Circulation (2004) 110:3674-9. doi:10.1161/01.CIR.0000149746.62908.BB

23. Filigheddu N, Gnocchi VF, Coscia M, Cappelli M, Porporato PE, Taulli R, et al. Ghrelin and des-acyl ghrelin promote differentiation and fusion of $\mathrm{C} 2 \mathrm{C} 12$ skeletal muscle cells. Mol Biol Cell (2007) 18:986-94. doi:10.1091/mbc.E06-050402

24. Porporato PE, Filigheddu N, Reano S, Ferrara M, Angelino E, Gnocchi VF, et al. Acylated and unacylated ghrelin impair skeletal muscle atrophy in mice. J Clin Invest (2013) 123:611-22. doi:10.1172/JCI39920

25. Strasser F, Lutz TA, Maeder MT, Thuerlimann B, Bueche D, Tschop M, et al. Safety, tolerability and pharmacokinetics of intravenous ghrelin for cancerrelated anorexia/cachexia: a randomised, placebo-controlled, double-blind, double-crossover study. Br J Cancer (2008) 98:300-8. doi:10.1038/sj.bjc.6604148

26. Muller TD, Perez-Tilve D, Tong J, Pfluger PT, Tschop MH. Ghrelin and its potential in the treatment of eating/wasting disorders and cachexia. J Cachexia Sarcopenia Muscle (2010) 1:159-67. doi:10.1007/s13539-010-0012-4

27. Sugiyama M, Yamaki A, Furuya M, Inomata N, Minamitake Y, Ohsuye K, et al. Ghrelin improves body weight loss and skeletal muscle catabolism associated with angiotensin II-induced cachexia in mice. Regul Pept (2012) 178:21-8. doi:10.1016/j.regpep.2012.06.003

28. Von Haehling S, Morley JE, Anker SD. From muscle wasting to sarcopenia and myopenia: update 2012. J Cachexia Sarcopenia Muscle (2012) 3:213-7. doi:10.1007/s13539-012-0089-z

29. Murray CD, Martin NM, Patterson M, Taylor SA, Ghatei MA, Kamm MA, et al. Ghrelin enhances gastric emptying in diabetic gastroparesis: a double blind, placebo controlled, crossover study. Gut (2005) 54:1693-8. doi:10.1136/gut. 2005.069088

30. Horvath TL, Castaneda T, Tang-Christensen M, Pagotto U, Tschop MH. Ghrelin as a potential anti-obesity target. Curr Pharm Des (2003) 9:1383-95. doi:10.2174/1381612033454748

31. Howard AD, Feighner SD, Cully DF, Arena JP, Liberator PA, Rosenblum CI, et al. A receptor in pituitary and hypothalamus that functions in growth hormone release. Science (1996) 273:974-7. doi:10.1126/science.273.5277.974

32. Gnanapavan S, Kola B, Bustin SA, Morris DG, McGee P, Fairclough P, et al. The tissue distribution of the mRNA of ghrelin and subtypes of its receptor, GHS-R, in humans. J Clin Endocrinol Metab (2002) 87:2988. doi:10.1210/jcem. 87.6.8739

33. Egecioglu E, Bjursell M, Ljungberg A, Dickson SL, Kopchick JJ, Bergstrom G, et al. Growth hormone receptor deficiency results in blunted ghrelin feeding response, obesity, and hypolipidemia in mice. Am J Physiol Endocrinol Metab (2006) 290:E317-25. doi:10.1152/ajpendo.00181.2005

34. Sun Y, Wang P, Zheng H, Smith RG. Ghrelin stimulation of growth hormone release and appetite is mediated through the growth hormone secretagogue receptor. Proc Natl Acad Sci U S A (2004) 101:4679-84. doi:10.1073/pnas. 0305930101

35. Gutierrez JA, Solenberg PJ, Perkins DR, Willency JA, Knierman MD, Jin Z, et al. Ghrelin octanoylation mediated by an orphan lipid transferase. Proc Natl Acad Sci U S A (2008) 105:6320-5. doi:10.1073/pnas.0800708105

36. Yang J, Zhao TJ, Goldstein JL, Brown MS. Inhibition of ghrelin O-acyltransferase (GOAT) by octanoylated pentapeptides. Proc Natl Acad Sci U S A (2008) 105:10750-5. doi:10.1073/pnas.0805353105

37. Muller TD, Tschop MH. Ghrelin - a key pleiotropic hormone-regulating systemic energy metabolism. Endocr Dev (2013) 25:91-100. doi:10.1159/ 000346590

38. De Vriese C, Gregoire F, Lema-Kisoka R, Waelbroeck M, Robberecht P, Delporte C. Ghrelin degradation by serum and tissue homogenates: identification of the cleavage sites. Endocrinology (2004) 145:4997-5005. doi:10.1210/en.2004-0569

39. Van Der Ploeg L, Laken H, Sharma S, Datta R, Halem H, Dong J, et al. Preclinical gastrointestinal prokinetic efficacy and endocrine effects of the ghrelin mimetic RM-131. Life Sci (2014) 109:20-9. doi:10.1016/j.lfs.2014.06.003

40. Deboer MD, Zhu XX, Levasseur P, Meguid MM, Suzuki S, Inui A, et al. Ghrelin treatment causes increased food intake and retention of lean body mass in a rat model of cancer cachexia. Endocrinology (2007) 148:3004-12. doi:10.1210/en.2007-0016

41. Tabarin A, Diz-Chaves Y, Consoli D, Monsaingeon M, Bale TL, Culler MD, et al. Role of the corticotropin-releasing factor receptor type 2 in the control of food intake in mice: a meal pattern analysis. Eur J Neurosci (2007) 26:2303-14. doi:10.1111/j.1460-9568.2007.05856.x

42. Strassburg S, Anker SD, Castaneda TR, Burget L, Perez-Tilve D, Pfluger PT, et al. Long-term effects of ghrelin and ghrelin receptor agonists on energy balance in rats. Am J Physiol Endocrinol Metab (2008) 295:E78-84. doi:10.1152/ajpendo. 00040.2008 
43. Hassouna R, Labarthe A, Zizzari P, Videau C, Culler M, Epelbaum J, et al. Actions of agonists and antagonists of the ghrelin/GHS-R pathway on GH secretion, appetite, and cFos activity. Front Endocrinol (Lausanne) (2013) 4:25. doi:10.3389/fendo.2013.00025

44. Shin A, Camilleri M, Busciglio I, Burton D, Smith SA, Vella A, et al. The ghrelin agonist RM-131 accelerates gastric emptying of solids and reduces symptoms in patients with type 1 diabetes mellitus. Clin Gastroenterol Hepatol (2013) 11:1453-1459e4. doi:10.1016/j.cgh.2013.04.019

45. Shin A, Camilleri M, Busciglio I, Burton D, Stoner E, Noonan P, et al. Randomized controlled phase Ib study of ghrelin agonist, RM-131, in type 2 diabetic women with delayed gastric emptying: pharmacokinetics and pharmacodynamics. Diabetes Care (2013) 36:41-8. doi:10.2337/dc12-1128

46. Deboer MD, Zhu X, Levasseur PR, Inui A, Hu Z, Han G, et al. Ghrelin treatment of chronic kidney disease: improvements in lean body mass and cytokine profile. Endocrinology (2008) 149:827-35. doi:10.1210/en.2007-1046

47. Palus S, Schur R, Akashi YJ, Bockmeyer B, Datta R, Halem H, et al. Ghrelin and its analogues, BIM-28131 and BIM-28125, improve body weight and regulate the expression of MuRF-1 and MAFbx in a rat heart failure model. PLoS One (2011) 6:e26865. doi:10.1371/journal.pone.0026865

48. Taicher GZ, Tinsley FC, Reiderman A, Heiman ML. Quantitative magnetic resonance (QMR) method for bone and whole-body-composition analysis. Anal Bioanal Chem (2003) 377:990-1002. doi:10.1007/s00216-003-2224-3

49. Charoenthongtrakul S, Giuliana D, Longo KA, Govek EK, Nolan A, Gagne S, et al. Enhanced gastrointestinal motility with orally active ghrelin receptor agonists. J Pharmacol Exp Ther (2009) 329:1178-86. doi:10.1124/jpet.108.150193

50. Wren AM, Seal LJ, Cohen MA, Brynes AE, Frost GS, Murphy KG, et al. Ghrelin enhances appetite and increases food intake in humans. J Clin Endocrinol Metab (2001) 86:5992. doi:10.1210/jcem.86.12.8111

51. Druce MR, Wren AM, Park AJ, Milton JE, Patterson M, Frost G, et al. Ghrelin increases food intake in obese as well as lean subjects. Int J Obes (Lond) (2005) 29:1130-6. doi:10.1038/sj.ijo.0803001

52. Garcia JM, Polvino WJ. Effect on body weight and safety of RC-1291, a novel, orally available ghrelin mimetic and growth hormone secretagogue: results of a phase I, randomized, placebo-controlled, multiple-dose study in healthy volunteers. Oncologist (2007) 12:594-600. doi:10.1634/theoncologist.12-5-594

53. Hotta M, Ohwada R, Akamizu T, Shibasaki T, Takano K, Kangawa K. Ghrelin increases hunger and food intake in patients with restricting-type anorexia nervosa: a pilot study. Endocr J (2009) 56:1119-28. doi:10.1507/endocri.K09E-168

54. Neary NM, Small CJ, Wren AM, Lee JL, Druce MR, Palmieri C, et al. Ghrelin increases energy intake in cancer patients with impaired appetite: acute, randomized, placebo-controlled trial. J Clin Endocrinol Metab (2004) 89:2832-6. doi:10.1210/jc.2003-031768

55. Nagaya N, Itoh T, Murakami S, Oya H, Uematsu M, Miyatake K, et al. Treatment of cachexia with ghrelin in patients with COPD. Chest (2005) 128:1187-93. doi:10.1378/chest.128.3.1187

56. Wynne K, Giannitsopoulou K, Small CJ, Patterson M, Frost G, Ghatei MA, et al. Subcutaneous ghrelin enhances acute food intake in malnourished patients who receive maintenance peritoneal dialysis: a randomized, placebo-controlled trial. J Am Soc Nephrol (2005) 16:2111-8. doi:10.1681/ASN.2005010039

57. Ashby DR, Ford HE, Wynne KJ, Wren AM, Murphy KG, Busbridge M, et al. Sustained appetite improvement in malnourished dialysis patients by daily ghrelin treatment. Kidney Int (2009) 76:199-206. doi:10.1038/ki.2009.114
58. Miljic D, Pekic S, Djurovic M, Doknic M, Milic N, Casanueva FF, et al. Ghrelin has partial or no effect on appetite, growth hormone, prolactin, and cortisol release in patients with anorexia nervosa. J Clin Endocrinol Metab (2006) 91:1491-5. doi:10.1210/jc.2005-2304

59. Akamizu T, Iwakura H, Ariyasu H, Hosoda H, Murayama T, Yokode M, et al. Repeated administration of ghrelin to patients with functional dyspepsia: its effects on food intake and appetite. Eur J Endocrinol (2008) 158:491-8. doi:10.1530/EJE-07-0768

60. Wargin W, Thomas H, Clohs L, St-Louis C, Ejskjaer N, Gutierrez M, et al. Contribution of protein binding to the pharmacokinetics of the ghrelin receptor agonist TZP-101 in healthy volunteers and adults with symptomatic gastroparesis: two randomized, double-blind studies and a binding profile study. Clin Drug Investig (2009) 29:409-18. doi:10.2165/00044011-200929060-00004

61. Ejskjaer N, Dimcevski G, Wo J, Hellstrom PM, Gormsen LC, Sarosiek I, et al. Safety and efficacy of ghrelin agonist TZP-101 in relieving symptoms in patients with diabetic gastroparesis: a randomized, placebo-controlled study. Neurogastroenterol Motil (2010) 22:1069-e1281. doi:10.1111/j.1365-2982.2010. 01519.x

62. Wo JM, Ejskjaer N, Hellstrom PM, Malik RA, Pezzullo JC, Shaughnessy L, et al. Randomised clinical trial: ghrelin agonist TZP-101 relieves gastroparesis associated with severe nausea and vomiting - randomised clinical study subset data. Aliment Pharmacol Ther (2011) 33:679-88. doi:10.1111/j.1365-2036.2010. 04567.x

63. Shaw M, Pediconi C, McVey D, Mondou E, Quinn J, Chamblin B, et al. Safety and efficacy of ulimorelin administered postoperatively to accelerate recovery of gastrointestinal motility following partial bowel resection: results of two randomized, placebo-controlled phase 3 trials. Dis Colon Rectum (2013) 56:888-97. doi:10.1097/DCR.0b013e31829196d0

64. Briggs DI, Enriori PJ, Lemus MB, Cowley MA, Andrews ZB. Diet-induced obesity causes ghrelin resistance in arcuate NPY/AgRP neurons. Endocrinology (2010) 151:4745-55. doi:10.1210/en.2010-0556

Conflict of Interest Statement: Lex H. T. Van der Ploeg is an employee of Rhythm Pharmaceuticals, Inc., which is developing RM-131 for the treatment of diabetic gastroparesis and other functional gastrointestinal disorders in humans. The other authors have no conflicts of interest to disclose.

Received: 29 August 2014; accepted: 18 December 2014; published online: 12 January 2015.

Citation: Fischer K, Finan B, Clemmensen C, van der Ploeg LHT, Tschöp MH and Müller TD (2015) The pentapeptide RM-131 promotes food intake and adiposity in wildtype mice but not in mice lacking the ghrelin receptor. Front. Nutr. 1:31. doi: 10.3389/fnut.2014.00031

This article was submitted to Eating Behavior, a section of the journal Frontiers in Nutrition.

Copyright () 2015 Fischer, Finan, Clemmensen, van der Ploeg, Tschöp and Müller. This is an open-access article distributed under the terms of the Creative Commons Attribution License (CC BY). The use, distribution or reproduction in other forums is permitted, provided the original author(s) or licensor are credited and that the original publication in this journal is cited, in accordance with accepted academic practice. No use, distribution or reproduction is permitted which does not comply with these terms. 